\title{
Evaluation of Climate Elasticity of Runoff based on Observed Rainfall, Streamflow and Simulated Future Streamflow using SWAT Model in Kelani Ganga Basin
}

\author{
K.K.G.I.L. Siriwardena and R.L.H.L. Rajapakse
}

\begin{abstract}
Kelani Ganga basin is the $7^{\text {th }}$ largest watershed in Sri Lanka, spanning over $2,292 \mathrm{~km}^{2}$ and annually discharging 4,225 MCM flow to the sea. The basin currently hosts over $19 \%$ of the country's population and is the primary source of drinking water to over 4 million people living in Greater Colombo. Hence, the present study was undertaken to evaluate the Climate Elasticity of Runoff based on observed rainfall, streamflow data and simulated future streamflow using the SWAT Model in the Kelani Ganga basin, targeting sustainable management of basin water resources in future. The runoff elasticity $(\varepsilon)$ is assessed by two methods for the present and 2040 scenarios. The selected three hydrometric gauging stations exhibit significant downward trends for the period of 1980 to 2016. An 80\% of the rain gauges in the middle and upper basin show significant decreasing trends for high to low rainfall totals for Yala season as per Innovative Trend Analysis (ITA) for the period of 1980 to 2016. Mass balance performance error (Er), Nash-Sutcliffe Efficiency (NSE) and Coefficient of determination $\left(R^{2}\right)$ are used as multi-objective functions and $8.90 \%, 0.65,0.72$ and $9.10 \%$, $0.69,0.69$ are obtained for the above objective functions in SWAT model for the calibration and validation periods of 1970 to 1980 and 1982 to 1992, respectively. A $1^{\circ} \mathrm{C}$ of temperature increase causes a $6.9 \%$ and $7.4 \%$ runoff decrease for the current scenario and it causes $0.4 \%$ increase and $1.5 \%$ decrease of runoff for Future Pessimistic Climate change Scenario as evaluated by the methods proposed by Zheng et al. [24] and Sankarasubramanian et al. [22], respectively. A 1\% of rainfall increase causes a runoff increase of $0.002 \%$ and $0.370 \%$ for the current scenario and a runoff increase of $0.005 \%$ and $0.360 \%$ for 2040 as evaluated by the two methods, respectively. It is recommended to further analyse the water allocation model for better results with practical implementations by considering the identified trend after 1995 in future research for better planning and management of water resources in future.
\end{abstract}

Keywords: Future pessimistic scenario, Innovative trend analysis, Mann-Kendal test, Sen's slope, Runoff elasticity

\section{Introduction}

\subsection{Overview}

The rapid population growth, urbanization and industrial expansion cause remarkable pressure on the available water resources in the Kelani Ganga basin. Climate change is an additional driver in the $21^{\text {st }}$ century [1]. Climate Change may affect water resources through impact on long-term water balance due to temperature changes, unusual spatio-temporal variability and sea-level rise, which lead to adverse implications for food security, water security, human livelihood and health, and ecosystems.

Surface temperature is currently increasing at $0.2{ }^{\circ} \mathrm{C}$ per decade and it is projected to increase by $1.5{ }^{\circ} \mathrm{C}$ by 2050, if the projected anthropogenic activities continue to increase at the current rate [2]. Thus, Climate change impacts will be a huge problem for developing countries because of their poor adaptation and mitigation measures to Climate change [3]. Sri Lanka also falls under this category, hence some effects may be irreversible or long-lasting, such as the loss of some ecosystems [2]. Climate elasticity of runoff defined as the proportional change in the runoff to the change in climatic variables such as Precipitation $(\mathrm{P})$, Temperature (T) etc., can be used in identifying basinwide impacts due to future Climate variability.

Climate change impacts will intensify the water crisis as well as natural disasters in the Kelani River basin in future. Hence a proper Climate trend analysis based on hydro-meteorological parameters in the basin for current and future scenarios is an essential and timely requirement, due to its highest basin population and as it is ranked as third ( $\left.3^{\text {rd }}\right)$ in

Eng. K.K.G.I.L. Siriwardena, AMIESL, BMIWA, MSLNCOLD, B.Sc. Eng. (Hons) (Moratuwa), M.Sc. Eng. (WREEM,Moratuwa), Engineer, Mahaweli Authority, Sri Lanka.Email:irnikalaksri@gmail.com

(iD https://orcid.org/0000-0002-5986-7480

Eng. (Prof.) R.L.H.L. Rajapakse, C. Eng., MIE(SL), B.Sc.

Eng. (Hons) (Moratuwa), M.Eng. (Saitama), PhD (Saitama),

Senior Lecturer in Civil Engineering, University of

Moratuwa, Sri Lanka.

Email:lalith@uom.lk

(iD https://orcid.org/0000-0002-7967-247X 
the country in terms of water resources. Therefore, it is vital to evaluate the climate trends for the past period of 1980 to 2016 considering climate elasticity of runoff based on observed rainfall and streamflow data. Not only that, but simulated future streamflow also using SWAT Model in Kelani River Basin for the planning and management of the basin water resources efficiently and sustainably in future.

\subsection{Hydrological Models and SWAT Model}

Hydrological models are very valuable tools to recognize the response to the issues in water resources planning and management [4]. Hydrological phenomena are highly nonlinear, highly variable and extremely complex in space and time [5]. Soil and Water Assessment Tool (SWAT) is a semi-distributed, physically-based rainfall-runoff model. It has become a powerful tool which measures the effects of Climate change on water resources planning and management in the recent past [6]. Calibrated SWAT model was used to simulate the potential effects of future Climate change on streamflow. Subsequently, the model was used to estimate rainfall-runoff elasticity in the Kelani River basin. This analysis ultimately facilitates the screening of more efficient and sustainable future water resources planning and management alternatives.

\subsection{Study Area}

Kelani River is the second largest river after Mahaweli Ganga by volume of discharge in
Sri Lanka [7]. It is the $7^{\text {th }}$ largest river basin in the country with a watershed area of $2,292 \mathrm{~km}^{2}$, annually contributing 4,225 MCM flow to the sea. It is bounded by Attanagalu Oya, Maha Oya, Mahaweli Ganga and Kalu Ganga basins. The Kelani basin is entirely located in the wet zone with the highest annual rainfall in Sri Lanka, with the annual average rainfall ranging between 2,000 $\mathrm{mm}$ to $5,700 \mathrm{~mm}$. The mean temperature varies a little over the year, between $28{ }^{\circ} \mathrm{C}$ and $30{ }^{\circ} \mathrm{C}$ in the basin. It flows along $145 \mathrm{~km}$ into the sea at Modara and elevation varies from 2,500 - 0 m AMSL from downstream to upstream.

The basin currently has a population of approximately 2.5 million. This amounts to more than $19 \%$ of the total Sri Lankan population in less than $4 \%$ of the total land extent. The population density is over 1,000 people per $\mathrm{km}^{2}$ in the Kelani basin. The population of the Kelani basin will rise to 3.3 million by 2040 , with an increase of about $31 \%$ from 2016 [8]. Water supply from the Kelani Ganga will experience deficits by the year 2025, even corresponding to 2 year return period daily average low flow value [9]. The basin also contains parts of the administrative districts of Kegalle (44\%), Colombo (19.6\%), Nuwara Eliya $(18.4 \%)$, Gampaha $(14.3 \%)$, Ratnapura (3\%), Kalutara $(0.5 \%)$ and Kandy $(0.2 \%)$ as shown in Figure 1. It is apparent that nearly two-thirds of the total area of the Colombo district $(64 \%)$ is situated within the Kelani Ganga basin.

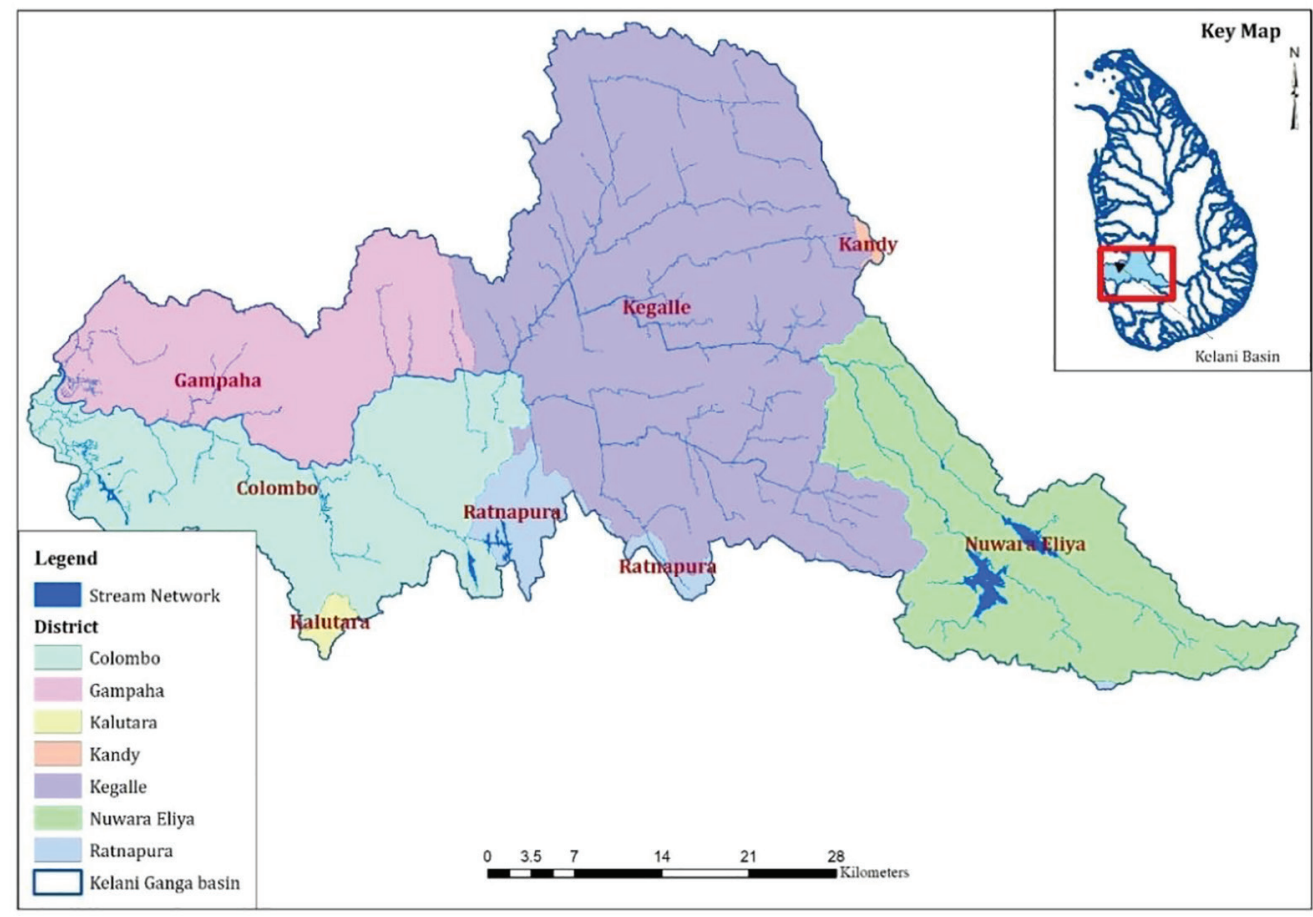

Figure 1 - District Boundaries and Stream Network in Kelani Ganga Basin 
Hence, it is vital to evaluate the Climate Elasticity of runoff based on observed rainfall and streamflow data and simulated future streamflow using the SWAT model in Kelani Ganga basin, as the above given factors clearly illustrate the importance of the assessment of water resources in Kelani Ganga basin.

\section{Study Approach and Setting}

In order to better understand the present water resources in the basin and Climate impacts on future water availability, the study focused on the existing basin water resources, their Climate, Climate trends and trend analysis.

\subsection{Climate Change}

A number of research have been carried out to identify Climate change impacts regionally as well as globally. Several General Circulation Models or Global Climatic Models (GCMs) and Regional Climatic Models (RCMs) have been developed to facilitate the analysis of climatic change. However, the situation related to Sri Lanka is quite different, since there are significant research gaps with respect to the Sri Lankan context and basin level estimates.

The future variations in Climate will subsequently have an impact on regional water resources and regional hydrologic conditions in terms of both quality and quantity [10, 11]. Potential effects may comprise changes in hydrological processes, hence research of global change on the hydrologic cycle plays a rising role [12]. IPCC confirms that global warming will be increased by $1.5^{\circ} \mathrm{C}$ by 2050 [2].

\subsection{Climate Trends in Sri Lanka}

Climate change has been predicted to affect the pattern of rainfall, hence would change the timing of the receipt of reservoir inflows [13]. In addition, the shifting of climatic zones would be expected due to Climate change. There will be a significant expansion of dry areas of the country by 2050 due to Climate change, thereby imposing significant pressure on water resources [4]. The regional and basin level rainfall trends, temperature trends, evaporation and evapotranspiration trends were identified during the literature review.

The World Meteorological Organization (WMO) guidelines on the standard climatological normal calculation endorse a rolling 30-year period, upgraded every 10 years for operational Climate monitoring [12]. The latest time range for the base year period is 1981 - 2010 [12].

\subsection{Analysis of Climate Change Impacts} Innovative Trend Analysis (ITA), MannKendall (M-K) test and Sen's slope tests were carried out to check the trends in hydrometeorological parameters such as rainfall, temperature and flow. These methods were used to analyse trends in annual and seasonal variations in each parameter. The four seasons were defined as First Inter Monsoon (FIM: March - April), South West Monsoon (SWM: May - September), Second Inter Monsoon (SIM: October - November) and North East Monsoon (NEM: December February). These tests were used to analyse Maha (October to April) and Yala (May to September) seasons as well. Mann-Kendall and Sen's slope methods were used to verify the results of Innovative Trend Analysis (ITA).

\subsubsection{Statistical Tests for Climate Impacts}

Three (3) main tests were carried out to check the trends in each hydrometeorological parameter.

- Innovative Trend Analysis (ITA)

- The Mann-Kendall Test (M-K test)

- $\quad$ Sen's slope Estimator (SSE)

\subsubsection{Mann-Kendall Test}

The Mann-Kendall test, proposed by Kendall $[16,17]$, is a non-parametric test, which is a widely used most popular method to detect trends in hydro-meteorological time series [14, 15]. The test statistic $S$ is given by:

$S=\sum_{i=1}^{n-1} \sum_{j=i+1}^{n} \operatorname{sgn}\left(x_{j}-x_{i}\right)$

where $n$ is the number of observations, $x_{i}$ and $x_{j}$ are the $i^{\text {th }}$ and $j^{\text {th }}(j>i)$ observations in the time series, and:

$\operatorname{Var}(S)=\frac{\boldsymbol{n}(\boldsymbol{n}-\mathbf{1})(\mathbf{2} \boldsymbol{n}+\mathbf{5})-\sum_{k=1}^{m}\left(t_{k}-1\right)\left(2 t_{k}+5\right)}{18}$

where $m$ is the number of tied groups and $t_{k}$ is the number of ties of extent $k$. The standard normal test statistic $Z$ used for detecting a significant trend is expressed as,

$Z=\left\{\begin{array}{ll}\frac{s-1}{\sqrt{\operatorname{Var}(S)}}, & \text { if } S>0 \\ 0, & \text { if } S=0 \\ \frac{S+1}{\sqrt{\operatorname{Var}(S)}}, & \text { if } S<0\end{array}\right\}$

A positive value of $Z$ indicates an upward trend, while a negative value of $Z$ indicates a downward trend.

\subsubsection{Sen's Slope Estimator}

Sen [16] developed a method to estimate the slope of the trend using a non-parametric procedure in the sample of $N$ pairs of data. The $N$ values of $Q_{i}$ are ranked from smallest to largest and the median of slope or Sen's slope estimator is computed as: 
largest and the median of slope or Sen's slope estimator is computed as:

$$
\begin{aligned}
& Q_{\text {med }} Q_{\left[\frac{N+1}{2}\right]}, \text { if } N \text { is odd } \\
& {\left[\frac{\left[(N+2) /{ }^{2}\right]+Q_{\left[\frac{N+1}{2}\right]}}{2} \text {, if } N \text { is even }\right\}}
\end{aligned}
$$

The $Q_{\text {med }}$ sign reflects data trend reflection, while its value indicates the steepness of the trend.

\subsubsection{Innovative Trend Analysis (ITA)}

The ITA has avoided the limitations of MannKendall test and Sen's slope estimator [18]. Sen introduced this new methodology on the basis of subsection time series plots derived from a given time series on a Cartesian coordinate system. In such a plot, trend free time-series subsections appear along the $45^{\circ}$ straight-line. Increasing (decreasing) trends occupy upper (lower) triangular areas of the square area defined by the variation domain of the variable concerned. The ITA values can be compared with the Mann-Kendall (M-K) trend test using the trend indicator, which is given by:

$D=\frac{1}{n} \sum_{i=1}^{n} 10 \frac{\left(y_{i}-x_{i}\right)}{\bar{x}}$

\subsection{The Climate Elasticity of Runoff}

Climate elasticity of runoff can be defined as the proportional change in the runoff to the change in climatic variables such as Precipitation $(\mathrm{P})$, Relative humidity $(\mathrm{RH})$ and Temperature (T), etc. [19]. Chiew [19] stated that the rainfall elasticity of streamflow is strongly correlated to runoff coefficient and mean annual rainfall and streamflow, where streamflow is more sensitive to rainfall in drier catchments, and those with low runoff coefficients. The nonparametric estimator is useful, where frequent evaluations of the longterm streamflow sensitivity to Climate are required because it is simple to apply and it evaluates the elasticity directly from the past data [20]. The analysis of the potential effects of Climate change on streamflow based on runoff elasticity is elucidated as follows.

The two-parameter Climate elasticity $(\varepsilon)$ as introduced by Fu et al. [21] and Yang and Yang [12] can be depicted as;

$$
\frac{d R}{R}=\varepsilon_{a} \frac{d P}{P}+\varepsilon_{b} \frac{d T}{T}
$$

where $\varepsilon_{a}$ and $\varepsilon_{b}$ are different elasticity components contributing to the overall change in streamflow $(R)$ as defined in the literature by Chiew [20], Sankarasubramanian et al. [22], and Niemann \& Eltahir, [23].
$\varepsilon=\operatorname{median}\left[\frac{\left(R_{i}-\bar{R}\right) / \bar{R}}{\left(X_{i}-\bar{X}\right) / \bar{X}}\right]$

But recently, Zheng et al. [24] suggested that the concept of Climate elasticity was used to assess the impacts of Climate and land surface change on the streamflow and they described $\varepsilon$ as following,

$\varepsilon=\frac{\bar{X}}{\bar{R}} \frac{\sum\left(X_{i}-\bar{X}\right)\left(R_{i}-\bar{R}\right)}{\sum\left(X_{i}-\bar{X}\right)^{2}}$

where $X$ represents the climatic variables (e.g.P, and $T$ ), and $R$ and $X$ represent the mean annual runoff and any climatic variable, respectively. During the study, the runoff elasticity is calculated from the 1980 to 2016 period.

\subsection{Hydrological Modelling}

Several hydrological models were considered and the assessment of strengths and weaknesses of these models were identified and model selection was rationalized using eight (8) criteria as given in Table 1.

\begin{tabular}{|c|c|c|c|c|}
\hline No. & Criteria & High (H) & Medium (M) & Low $(\mathrm{L})$ \\
\hline 1. & $\begin{array}{c}\text { Model } \\
\text { application }\end{array}$ & $\begin{array}{l}\text { Applied in Sri } \\
\text { Lanka }\end{array}$ & $\begin{array}{l}\text { Applied in } \\
\text { Asian region }\end{array}$ & $\begin{array}{c}\text { Applied in } \\
\text { other } \\
\text { regions }\end{array}$ \\
\hline 2. & \begin{tabular}{|} 
Assessing the \\
Climate \\
Change \\
Impacts
\end{tabular} & Highly used & $\begin{array}{c}\text { Moderately } \\
\text { used }\end{array}$ & $\begin{array}{c}\text { Rarely } \\
\text { used }\end{array}$ \\
\hline 3. & $\begin{array}{c}\text { Time of } \\
\text { simulation }\end{array}$ & $\begin{array}{c}\text { Continuous } \\
\text { and event base }\end{array}$ & Continuous & Event base \\
\hline 4. & $\begin{array}{c}\text { Model } \\
\text { accessibility }\end{array}$ & Freely available & \begin{tabular}{|c|} 
Freely \\
available for \\
education \\
purpose
\end{tabular} & $\begin{array}{c}\text { Fully } \\
\text { commercial }\end{array}$ \\
\hline 5. & \begin{tabular}{|c|} 
Physical \\
process \\
representation
\end{tabular} & $\begin{array}{c}\text { Physics based } \\
\text { model }\end{array}$ & $\begin{array}{c}\text { Conceptual } \\
\text { model }\end{array}$ & $\begin{array}{c}\text { Empirical } \\
\text { model }\end{array}$ \\
\hline 6. & $\begin{array}{l}\text { Temporal } \\
\text { resolution }\end{array}$ & Sub daily, daily & Monthly & Annually \\
\hline 7. & $\begin{array}{c}\text { Data } \\
\text { requirement }\end{array}$ & $\begin{array}{c}\text { Model runs } \\
\text { with limited } \\
\text { data } \\
\text { availability }\end{array}$ & $\begin{array}{c}\text { Model runs } \\
\text { with } \\
\text { moderate } \\
\text { limited data } \\
\text { availability } \\
\end{array}$ & $\begin{array}{c}\text { Model runs } \\
\text { with more } \\
\text { data } \\
\text { availability }\end{array}$ \\
\hline 8. & $\begin{array}{c}\text { Availability of } \\
\text { manuals and } \\
\text { quick guides }\end{array}$ & $\begin{array}{c}\text { Freely available } \\
\text { user guides } \\
\text { and manuals }\end{array}$ & $\begin{array}{c}\text { Commercially } \\
\text { available user } \\
\text { guides and } \\
\text { manuals }\end{array}$ & \begin{tabular}{|c|} 
None \\
availability \\
of manuals \\
and guides
\end{tabular} \\
\hline
\end{tabular}

Table 1 - Model Selection Rational Criteria

Distinct weightages were given for each criterion for the selection of the model and the ranking for model selection is given in Table 2 .

The Soil and Water Assessment Tool (SWAT) model ranked the highest in the model ranking process, hence it was selected for the present analysis.

The reviews of SWAT model components and their applications are reported in over 1,000 published peer-reviewed articles worldwide. Most SWAT parameters can be assessed automatically using the weather information 
Table 2 - Ranking for Model Selection

\begin{tabular}{|c|c|c|c|c|c|c|}
\hline Criteria & SWAT & $\begin{array}{c}\text { TOP } \\
\text { MODEL }\end{array}$ & $\begin{array}{c}\text { MIKE } \\
\text { 11/ } \\
\text { NAM } \\
\end{array}$ & TANK & $\begin{array}{l}\text { HEC- } \\
\text { HMS }\end{array}$ & $A B C D$ \\
\hline 1 & $\mathrm{H}(3)$ & $\mathrm{H}(3)$ & $\mathrm{H}(3)$ & $\mathrm{H}(3)$ & $\mathrm{H}(3)$ & L (1) \\
\hline 2 & $\mathrm{H}(3)$ & L (1) & L (1) & L (1) & $\mathrm{L}(1)$ & L (1) \\
\hline 3 & $\mathrm{H}(3)$ & L (1) & $\mathrm{M}(2)$ & M (2) & $\mathrm{H}(3)$ & M (2) \\
\hline 4 & $\mathrm{H}(3)$ & $\mathrm{H}(3)$ & $\mathrm{M}(2)$ & M (2) & $\mathrm{H}(3)$ & $\mathrm{H}(3)$ \\
\hline 5 & $\mathrm{H}(3)$ & $\mathrm{M}(2)$ & $\mathrm{M}(2)$ & M (2) & $\mathrm{H}(3)$ & L (1) \\
\hline 6 & $\mathrm{H}(3)$ & $\mathrm{H}(3)$ & $\mathrm{H}(3)$ & $\mathrm{H}(3)$ & $\mathrm{H}(3)$ & $\mathrm{H}(3)$ \\
\hline 7 & $\mathrm{M}(2)$ & L (1) & $\mathrm{H}(3)$ & $\mathrm{H}(3)$ & $\mathrm{H}(3)$ & L (1) \\
\hline 8 & $\mathrm{H}(3)$ & $\mathrm{L}(1)$ & $\mathrm{H}(3)$ & $\mathrm{L}(1)$ & $\mathrm{H}(3)$ & $\mathrm{H}(3)$ \\
\hline Total & 23 & 15 & 19 & 17 & 22 & 15 \\
\hline
\end{tabular}

The governing equation in the SWAT model is given below [26].

$S W_{t}=S W_{o}+\sum\left(R_{\text {day }}-Q_{\text {surf }}-E_{a}-W_{\text {seep }}-Q_{g w}\right)$

where $S W_{t}=$ Final soil water content $(\mathrm{mm})$

$S W_{o}=$ Initial soil water content on day $i(\mathrm{~mm})$

$R_{\text {day }}=$ Amount of precipitation on day $i(\mathrm{~mm})$

$Q_{\text {surf }}=$ Amount of surface runoff on day $i(\mathrm{~mm})$

$E_{a}=$ Amount of evaporation on day $i(\mathrm{~mm})$

$W_{\text {seep }}=$ Amount of water entering the vadose zone

from soil profile on day $i(\mathrm{~mm})$

$Q_{g w}=$ Amount of return flow on day $i(\mathrm{~mm})$

\section{Materials and Methods}

The research methods followed and the data used in the present study are explained below.

\subsection{Methodology}

The methodology adopted for this research is briefly described as follows.

- During the literature review, research gaps, the extent of analysis and prevailing issues were identified. The research objectives and specific objectives were originated.

- The study area was selected based on the research gaps and other identified issues during the literature survey.

- Data collection was initiated and data checking was carried out for all meteorological and hydrological data series and the missing data threshold is taken as less than $10 \%$ for all time series data.

- Gap-filling was carried out for all five (5) alpha parameters for rainfall and temperature data using Inverse Distance Weighting (IDW).

- Three (3) streamflow (hydrometric) stations were selected among six (6) hydrometric stations based on the data quality. Gap filling of streamflow was carried out using linear interpolation and nearby station's records.

- Root-mean-square error (RMSE) was calculated for each month and each percentile to determine the most suitable combination of power value (a) for both rainfall and temperature time series in the analysis.

- Statistical tests were carried out for the optimized alpha parameter to identify consistency and homogeneity of the data series as well as to identify trends of Climate change for the duration of 1980 - 2016 using ITA, Mann-Kendall test and Sen's slope test.

- The SWAT model is selected based on Model selection rational criteria and the model was built to simulate the streamflow for the selected duration of 1960 to 2016.

- The SWAT model was calibrated and validated for the key hydrometric station at Glencourse.

- The applicability of the same hydrological parameters, which were used for Glencourse, was also evaluated for Hanwella and Kitulgala gauging stations in the basin.

- Future rainfall and temperature series already derived for pessimistic Climate change scenarios and landuse for 2040 [8] were used to simulate the future flow series in the Kelani Ganga basin using the SWAT model for 2040.

- The runoff elasticity $(\varepsilon)$ was assessed by two methods based on the assessment of impacts of Climate change only and impacts of Climate and land surface change on the streamflow, as evaluated by Sankarasubramanian et al. [22] and Zheng et al. [24], respectively for the current and the future pessimistic Climate change scenarios for 2040 .

\subsection{Data and Data Checking}

Several tests were performed during data checking such as visual data checking, outlier checking, graphical checking, and consistency and homogeneity checking using:

- a time-series plot of the annual rainfall totals;

- a time-series plot of the normalised annual rainfall totals;

- a normal probability plot; and

- single mass and double mass analysis plot

Daily data were collected for the period of 56 years starting from 1960/61 water year to 2015/2016 water year. From the selected 41 rainfall stations, 17 rainfall stations are located within the Kelani River basin, while 24 rainfall 
stations located in the surroundings of the Kelani River basin were used for gap-filling using Inverse Distance Weighting (IDW).

Accordingly, rainfall, evaporation, temperature, streamflow data and spatial information for all hydrometric stations were collected from different organizations in Sri Lanka. Table 3 summarises the details of data availability for the analysis. All the collected data were preprocessed to restructure the raw data into time series during the initial stage of data collection.

Data inconsistency, missing data, and outliers were assessed visually for the collected hydrometeorological data including streamflow, rainfall, maximum temperature $\left(T_{\max }\right)$ and minimum temperature $\left(T_{\min }\right)$ data.

Using the land use maps developed by the Land Use Policy Planning Department (LUPPD) and the growth and constraint factors developed as part of the population growth analysis, the existing land use maps were updated to represent the projected land use change in 2040 [8] for SWAT modelling.

Furthermore, the double mass curves and annual water balance were also used to identify the data inconsistency and/or homogeneity. Key components of the SWAT model are weather, surface runoff, return flow, percolation, evapotranspiration, transmission losses, pond and reservoir storage, crop growth and irrigation, groundwater flow, reach routing, nutrient and pesticide loading, and water transfer [19].

Table 3 - Summary Details of Data availability

\begin{tabular}{|c|c|c|c|c|}
\hline No. & Data & $\begin{array}{l}\text { Layer/ } \\
\text { Data } \\
\text { type }\end{array}$ & $\begin{array}{l}\text { Spatial } \\
\text { Resoluti } \\
\text { on/ time } \\
\text { step }\end{array}$ & $\begin{array}{c}\text { Source/ } \\
\text { Availability/ } \\
\text { Accessibility }\end{array}$ \\
\hline 01. & $\begin{array}{c}\text { Rainfall } \\
\text { data }\end{array}$ & $\begin{array}{l}\text { Vector/ } \\
\text { Time } \\
\text { series }\end{array}$ & $\begin{array}{l}\text { 1:10,000 } \\
\text { / Daily } \\
\text { time } \\
\text { step }\end{array}$ & $\begin{array}{l}\text { Department of } \\
\text { Meteorology }\end{array}$ \\
\hline 02. & $\begin{array}{c}\text { Temper } \\
\text { ature } \\
\text { data }\end{array}$ & $\begin{array}{l}\text { Vector/ } \\
\text { Time } \\
\text { series }\end{array}$ & $\begin{array}{l}\text { 1:10,000 } \\
\text { / Daily } \\
\text { time } \\
\text { step }\end{array}$ & $\begin{array}{l}\text { Department of } \\
\text { Meteorology }\end{array}$ \\
\hline 03. & $\begin{array}{l}\text { Evapor } \\
\text { ation } \\
\text { data }\end{array}$ & $\begin{array}{l}\text { Vector/ } \\
\text { Time } \\
\text { series }\end{array}$ & $\begin{array}{l}\text { 1:10,000 } \\
\text { / Daily } \\
\text { time } \\
\text { step }\end{array}$ & $\begin{array}{l}\text { Department of } \\
\text { Meteorology }\end{array}$ \\
\hline 04. & DEM & Raster & $30 \mathrm{~m}$ & $\begin{array}{c}\text { Survey } \\
\text { Department }\end{array}$ \\
\hline 05. & $\begin{array}{l}\text { Soil } \\
\text { data }\end{array}$ & Vector & $\begin{array}{c}1: \\
250,000\end{array}$ & $\begin{array}{c}\text { Soil Science } \\
\text { Society of Sri } \\
\text { Lanka (SSSSL) }\end{array}$ \\
\hline 06. & $\begin{array}{l}\text { Landus } \\
\text { e data }\end{array}$ & Vector & 1: 10,000 & $\begin{array}{c}\text { Landuse Policy } \\
\text { Planning } \\
\text { Department } \\
\text { (LUPPD) } \\
\end{array}$ \\
\hline 07. & $\begin{array}{c}\text { basin } \\
\text { Bounda } \\
\text { ries }\end{array}$ & Vector & 1: 10,000 & DSWRPP \\
\hline 08. & $\begin{array}{c}\text { Stream } \\
\text { paths }\end{array}$ & Vector & 1: 10,000 & $\begin{array}{c}\text { Department of } \\
\text { Survey }\end{array}$ \\
\hline 09. & $\begin{array}{l}\text { Reservo } \\
\text { ir data }\end{array}$ & $\begin{array}{l}\text { Vector / } \\
\text { timeseri } \\
\text { es }\end{array}$ & $\begin{array}{l}\text { 1:10,000 } \\
\text { / Daily } \\
\text { time } \\
\text { step }\end{array}$ & $\begin{array}{l}\text { Ceylon } \\
\text { Electricity } \\
\text { Board }\end{array}$ \\
\hline 10. & $\begin{array}{l}\text { Agro- } \\
\text { ecologic } \\
\text { al zones }\end{array}$ & Vector & $\begin{array}{c}1: \\
500,000\end{array}$ & $\begin{array}{c}\text { Department of } \\
\text { Agriculture }\end{array}$ \\
\hline
\end{tabular}

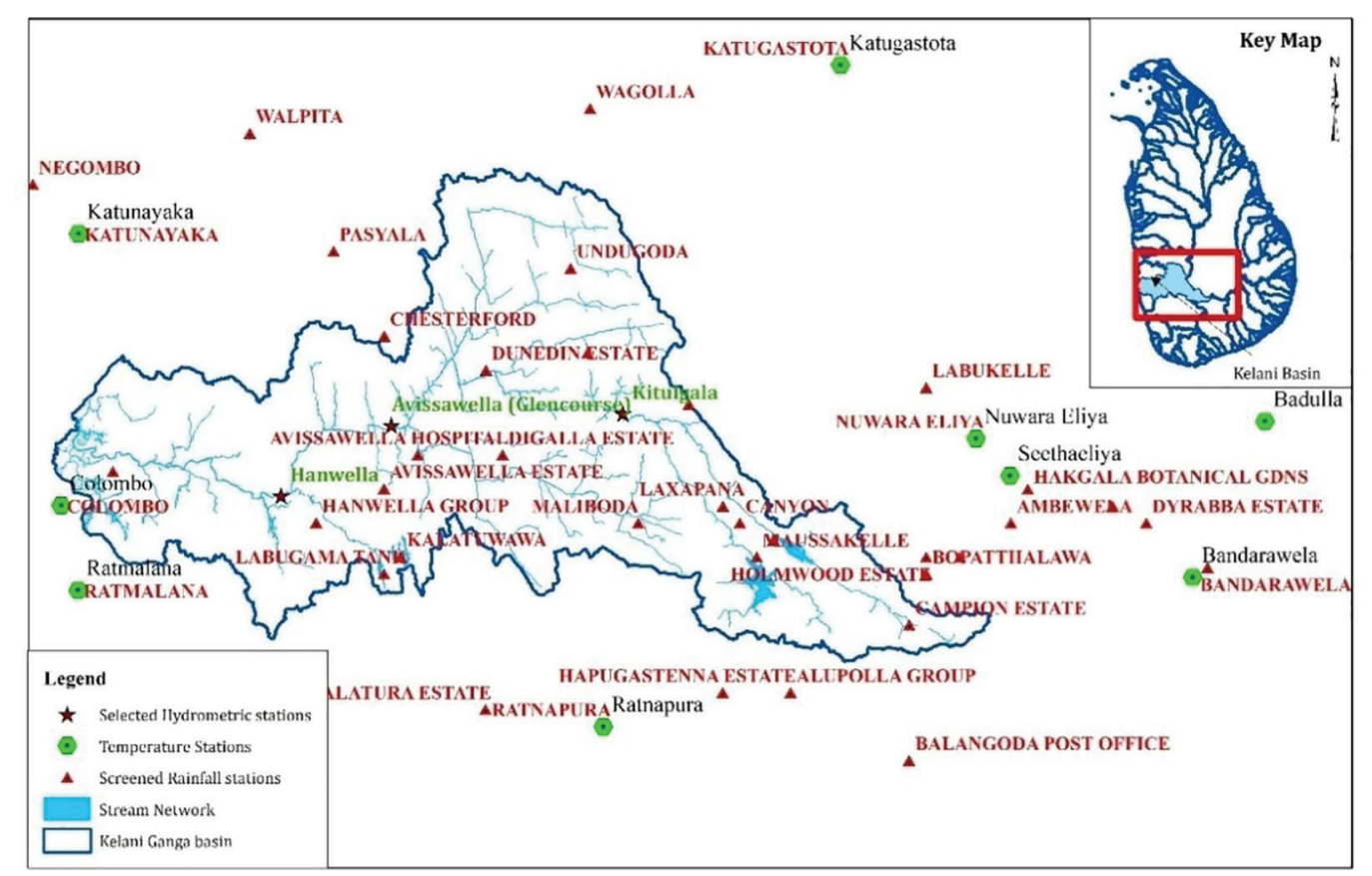

Figure 2 - Selected Rainfall, Temperature and Hydrometric Gauging Stations in Kelani Ganga Basin 
Key inputs to the model are Digital Elevation Model (DEM), river network, reservoirs and ponds, land use, soil and slope. There are more than 50 state variables described in the SWAT manual [26] and among those variables, the key state variables which can be used for model calibration and validation were selected for the study.

\section{Results and Discussion}

\subsection{Climate Trend Analysis \\ 4.1.1 Climate Trend Analysis based on Rainfall}

Innovative Trend Analysis (ITA) results are plotted using Python scripting for annual totals for the selected 41 rainfall stations (Table 4 ) and selected plots for the stations are shown in Figure 3. Though one of the most commonly used non-parametric trend tests is the MannKendall trend test, the main drawback of the test is that the auto-correlation and nonnormality of time series are ignored. This can be eliminated by using the Modified MannKendal test [27]. Innovative trend analysis (ITA) provides visual inspection and identification of categorical trends, which are not explicitly shown by the other tests such as Mann-Kendall and Sen's slope tests. Significant increasing trends are exhibited by M-K test for annual rainfall totals of Colombo, Negombo and Walpita rainfall stations at $10 \%$ confidence level and Angoda Mental Hospital and Pasyala rainfall stations at 5\% confidence level, while significant decreasing trends are exhibited for annual rainfall totals of Hanwella Group and Sandringham Estate at $10 \%$ confidence level, and Laxapana and Maussakele stations at 5\% confidence level.

The Sen's slope trend magnitude varies between -30.2 to 30.0 for annual rainfall totals for the period of 1980-2016. Chesterford exhibits the highest upward trend, while Laxapana shows the highest downward annual trend. Castlereigh station shows a serial correlation. Nevertheless, it shows a positive trend even for M-K test. Significant increasing trends are exhibited by $\mathrm{M}-\mathrm{K}$ test for the rainfall totals for Maha season for Holmwood Estate and Kalatuwawa rainfall stations at $10 \%$ confidence level and for Ambewela, Angoda Mental Hospital, Campion Estate, Negombo, Welimada Group and Pasyala rainfall stations at $5 \%$ confidence level, while no significant negative trends are exhibited by M-K test for the rainfall totals for Maha season. The Sen's slope trend magnitude varies between -12.0 to
16.5 for Maha rainfall totals for the period of 1980 to 2016. Negombo exhibits the highest upward trend, while Hanwella Group shows the highest downward trend for Maha season.

Significant increasing trends are exhibited by M-K test for the rainfall totals for Yala season for Avissawella Estate, Colombo and Walpita rainfall stations at $10 \%$ confidence level and for Chesterford rainfall station at 5\% confidence level, while significant negative trends are exhibited for Maussakele and Wagolla by M-K test for the rainfall totals for Yala season. The Sen's slope trend magnitude varies between 45.6 to 28.8 for Yala rainfall totals for the period of 1980 to 2016. Chesterford exhibits the highest upward trend, while Laxapana shows the highest downward trend for the Yala season.
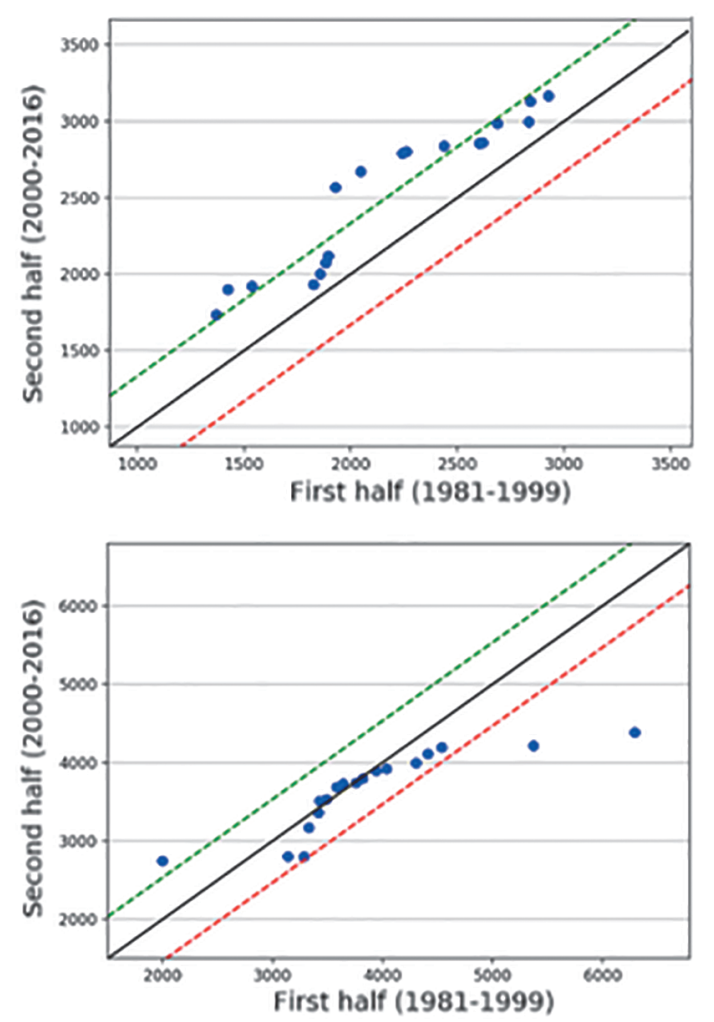

Figure 3 - Innovative Trend Analysis (ITA) Plots for Annual Totals for Angoda Mental Hospital (top) and Digalla Estate (bottom) Stations

Rainfall stations in the upper basin and lower basin show increasing trends for annual and Maha totals of rainfall for the high and medium region. Most of the rain gauges in the middle and upper basins in the Kelani Ganga basin show significant decreasing trends for high to low rainfall totals for Yala season as ITA analysis for the period of 1980 to 2016. 
Even though there are many publications on rainfall trends in the basin, the selected data durations for the trend analysis are different. Therefore, the comparison of rainfall durations for the selected duration of 1980-2010 was based on [28] and Table 5 shows that all given trends clearly tally with the published trend analysis.

\subsubsection{Climate Trend Analysis based on Temperature Data}

\subsubsection{Climate Trend Analysis based on Maximum Temperature $\left(T_{\text {max }}\right)$}

Katunayaka station exhibits a significant decreasing trend in $\mathrm{M}-\mathrm{K}$ test for annual averages and averages of Yala season at $10 \%$ confidence level, while it shows a significant decreasing trend for Maha season at 5\% confidence level for the period of 1980 to 2016
(Table 6). The Sen's slope trend magnitude varies between -0.2 to 0.1 for annual, Maha and Yala averages for the period of 1980-2016. Badulla exhibits the highest downward trend for Maha and Yala seasons.

\subsubsection{Climate Trend Analysis based on Minimum Temperature $\left(T_{\text {min }}\right)$}

Katunayaka station exhibits a significant increasing trend in $\mathrm{M}-\mathrm{K}$ test for annual averages at a $10 \%$ confidence level, while it shows a significant increasing trend for Maha season at a $5 \%$ confidence level for the period of 1980 to 2016 (Table 7). The Sen's slope trend magnitude varies between 0.0 to 0.3 for all annual, Maha and Yala averages for the period of 1980-2016. Katunayaka exhibits the highest upward trend for annual, Maha and Yala seasons.

Table 4 - The Trend Analysis of Rainfall Stations in and around Kelani Ganga Basin Based on ITA, M-K and Sen's Slope Estimates based on Annual data, Maha Season and Yala Season

\begin{tabular}{|c|c|c|c|c|c|c|c|c|c|}
\hline \multirow{2}{*}{$\begin{array}{c}\text { Name of the } \\
\text { Rainfall } \\
\text { Station }\end{array}$} & \multicolumn{3}{|c|}{ Annual Trend } & \multicolumn{3}{|c|}{ Trend in Maha Season } & \multicolumn{3}{|c|}{ Trend in Yala Season } \\
\hline & $\begin{array}{l}D \text { in } \\
\text { ITA }\end{array}$ & $\begin{array}{l}Z \text { in } \\
M-K \\
\text { test }^{1}\end{array}$ & $\begin{array}{l}Q_{m e d} \text { in } \\
\text { SSE }\end{array}$ & $\begin{array}{l}D \text { in } \\
\text { ITA }\end{array}$ & $\begin{array}{l}Z \text { in } \\
M-K \\
\text { test }^{1}\end{array}$ & $\begin{array}{l}Q_{\text {medin }} \text { in } \\
\text { SSE }\end{array}$ & $\begin{array}{l}D \text { in } \\
\text { ITA }\end{array}$ & $\begin{array}{l}Z \text { in } \\
M-K \\
\text { test }^{1}\end{array}$ & $Q_{m e d}$ inSSE \\
\hline Alupolla Group & 0.66 & 0.99 & 12.90 & 1.21 & 1.05 & 7.17 & 0.25 & 0.89 & 11.81 \\
\hline Ambewela & -0.93 & -0.29 & -2.54 & 1.53 & 2.06 & 11.90 & -2.70 & -0.50 & -6.23 \\
\hline $\begin{array}{l}\text { Angoda Mental } \\
\text { Hospital }\end{array}$ & 1.56 & 2.38 & 19.65 & 2.89 & 2.00 & 12.39 & 0.57 & 3.01 & 20.83 \\
\hline $\begin{array}{l}\text { Avissawella } \\
\text { Estate }\end{array}$ & -0.52 & -1.27 & -18.68 & 0.20 & -0.75 & -7.79 & -1.06 & -0.56 & -8.82 \\
\hline $\begin{array}{l}\text { Avissawella } \\
\text { Hospital }\end{array}$ & 0.55 & 1.21 & 13.57 & 1.41 & 0.96 & 12.58 & -0.12 & 1.74 & 19.95 \\
\hline $\begin{array}{l}\text { Balangoda Post } \\
\text { Office }\end{array}$ & 0.00 & 0.18 & 1.27 & 1.09 & 0.94 & 6.40 & -1.34 & 0.15 & 1.08 \\
\hline Bandarawela & 0.43 & 0.91 & 4.08 & 0.71 & 1.11 & 6.81 & 0.02 & 0.17 & 1.64 \\
\hline Bopatthalawa & -1.13 & -1.57 & -10.11 & 0.68 & 1.02 & 4.42 & -2.33 & -1.46 & -9.58 \\
\hline Campion Estate & 0.14 & 0.80 & 7.02 & 1.73 & 2.30 & 12.91 & -1.19 & 1.19 & 8.72 \\
\hline Canyon & -0.79 & -1.51 & -17.46 & 0.63 & 0.67 & 2.53 & -1.32 & -1.10 & -14.14 \\
\hline Castlereigh & 0.19 & 0.26 & 2.91 & 2.48 & 0.99 & 8.97 & -0.70 & -1.29 & -20.92 \\
\hline Chesterford & 1.49 & 2.68 & 30.01 & 1.79 & 0.88 & 10.01 & 1.25 & 2.04 & 28.78 \\
\hline Colombo & 0.57 & 1.73 & 11.25 & 1.77 & 1.38 & 7.38 & -0.39 & 1.87 & 10.60 \\
\hline Digalla Estate & -0.60 & -0.86 & -8.21 & 0.40 & 0.01 & 0.35 & -1.23 & -0.37 & -4.57 \\
\hline Dunedin_Estate & -0.29 & 0.00 & -0.21 & 0.62 & 1.41 & 12.91 & -0.94 & 1.26 & 17.99 \\
\hline Dyrabba_Estate & -0.75 & 0.15 & 0.91 & 0.35 & 1.07 & 6.17 & -2.34 & -0.21 & -2.71 \\
\hline Galatura_Estate & -0.23 & -0.23 & -2.66 & 0.40 & 0.32 & 3.10 & -0.63 & -0.36 & -5.17 \\
\hline $\begin{array}{l}\text { Hakgala } \\
\text { Botanical Gdns }\end{array}$ & 0.24 & 1.35 & 11.90 & 1.38 & 1.56 & 14.14 & -1.26 & 0.99 & 12.63 \\
\hline $\begin{array}{l}\text { Hanwella } \\
\text { Group }\end{array}$ & -1.09 & -1.92 & -22.88 & -0.60 & -1.41 & -12.04 & -1.49 & -2.68 & -32.61 \\
\hline $\begin{array}{l}\text { Hapugastenna } \\
\text { Estate }\end{array}$ & -0.52 & -1.02 & -14.17 & 0.52 & -0.84 & -10.47 & -1.14 & -1.63 & -29.84 \\
\hline
\end{tabular}

1 The colours used to show the significance of trends in M-K test are Orange, Green, Blue and Yellow for $10 \%$ for $5 \%$, for $1 \%$ and for $0.1 \%$ levels of significance, respectively. 


\begin{tabular}{|c|c|c|c|c|c|c|c|c|c|}
\hline \multirow{2}{*}{$\begin{array}{l}\text { Name of the } \\
\text { Rainfall } \\
\text { Station }\end{array}$} & \multicolumn{3}{|c|}{ Annual Trend } & \multicolumn{3}{|c|}{ Trend in Maha Season } & \multicolumn{3}{|c|}{ Trend in Yala Season } \\
\hline & $\begin{array}{l}D \text { in } \\
\text { ITA }\end{array}$ & $\begin{array}{l}Z \text { in } \\
M-K \\
\text { test }^{1}\end{array}$ & $\begin{array}{l}Q_{m e d} \text { in } \\
\text { SSE }\end{array}$ & $\begin{array}{l}D \text { in } \\
\text { ITA }\end{array}$ & $\begin{array}{l}Z \text { in } \\
M-K \\
\text { test }^{1}\end{array}$ & $\begin{array}{l}Q_{m e d} \text { in } \\
\text { SSE }\end{array}$ & $\begin{array}{l}D \text { in } \\
\text { ITA }\end{array}$ & $\begin{array}{l}Z \text { in } \\
M-K \\
\text { test }^{1}\end{array}$ & $Q_{m e d}$ inSSE \\
\hline $\begin{array}{l}\text { Holmwood } \\
\text { Estate }\end{array}$ & -0.34 & -0.12 & -1.16 & 0.89 & 1.89 & 12.17 & -1.19 & 0.99 & 5.63 \\
\hline Kalatuwawa & -0.02 & 0.04 & 0.73 & 0.62 & 0.66 & 6.42 & -0.51 & 0.36 & 3.99 \\
\hline Katugastota & 0.62 & 1.10 & 8.24 & 2.20 & 1.71 & 14.55 & -1.13 & 0.96 & 6.51 \\
\hline Katunayaka & 0.57 & 0.31 & 1.81 & 1.84 & 0.77 & 6.56 & -0.57 & 0.32 & 3.38 \\
\hline $\begin{array}{l}\text { Kenilworth } \\
\text { Strathellie }\end{array}$ & 0.37 & 0.64 & 14.03 & 1.73 & 1.43 & 14.87 & -0.19 & 0.42 & 9.86 \\
\hline $\begin{array}{l}\text { Labugama } \\
\text { Tank }\end{array}$ & 0.25 & 0.69 & 5.97 & 1.03 & 1.18 & 10.79 & -0.36 & 0.47 & 3.68 \\
\hline Labukelle & -1.18 & -0.89 & -13.63 & 0.59 & 0.39 & 4.47 & -2.25 & -0.96 & -18.37 \\
\hline Laxapana & -1.40 & -2.11 & -30.16 & -0.23 & -0.43 & -4.10 & -1.91 & -2.79 & -45.59 \\
\hline Maliboda & 0.35 & 1.05 & 14.40 & 0.72 & -0.21 & -3.53 & 0.15 & -0.02 & -1.91 \\
\hline Maussakelle & -1.14 & -2.03 & -19.10 & -0.12 & 0.24 & 2.48 & -1.61 & -2.38 & -30.43 \\
\hline Negombo & 2.17 & 1.92 & 12.01 & 3.65 & 2.23 & 16.51 & 0.81 & 2.61 & 17.79 \\
\hline Nuwara Eliya & -0.80 & -0.86 & -6.41 & 1.09 & 1.26 & 8.23 & -2.30 & -1.26 & -8.92 \\
\hline Pasyala & 1.15 & 2.30 & 16.34 & 1.73 & 2.08 & 15.89 & 0.65 & 1.48 & 13.00 \\
\hline Rathmalana & 0.99 & 1.29 & 8.66 & 2.35 & 0.99 & 7.68 & -0.08 & 1.18 & 9.73 \\
\hline Rathnapura & -0.08 & -0.01 & -0.23 & 0.52 & 0.47 & 5.04 & -0.49 & -0.24 & -3.94 \\
\hline $\begin{array}{l}\text { Sandringham } \\
\text { Estate }\end{array}$ & -1.27 & -1.65 & -9.72 & 0.17 & 0.66 & 3.68 & -2.25 & -0.96 & -10.90 \\
\hline Undugoda & -1.26 & -0.91 & -10.57 & -0.55 & 0.32 & 6.16 & -1.78 & -0.51 & -8.97 \\
\hline Wagolla & -1.63 & -2.22 & -15.72 & -0.39 & -1.26 & -8.25 & -2.78 & -2.42 & -16.83 \\
\hline Walpita & 1.27 & 1.89 & 13.44 & 1.64 & 0.92 & 6.62 & 0.95 & 1.93 & 12.75 \\
\hline $\begin{array}{l}\text { Welimada } \\
\text { Group }\end{array}$ & 1.60 & 2.66 & 9.39 & 1.87 & 2.19 & 11.45 & 1.15 & 1.48 & 7.60 \\
\hline $\begin{array}{l}\text { Weweltalawa } \\
\text { Estate }\end{array}$ & -0.31 & 0.50 & 8.58 & 0.83 & 0.77 & 12.13 & -0.93 & 0.69 & 17.11 \\
\hline
\end{tabular}

Table 5 - The Regression Coefficients of the Trend Analysis of Rainfall Stations in and around Kelani Ganga Basin as per [28] and Trend in this Publication

\begin{tabular}{|l|c|c|l|c|c|}
\hline \multicolumn{1}{|c|}{ Station Name } & $\begin{array}{c}\text { Trend as } \\
\text { per [31] }\end{array}$ & $\begin{array}{c}\text { Trend in this } \\
\text { publication }\end{array}$ & \multicolumn{1}{|c|}{ Station Name } & $\begin{array}{c}\text { Trend as } \\
\text { per [31] }\end{array}$ & $\begin{array}{c}\text { Trend in this } \\
\text { publication }\end{array}$ \\
\hline Sandringham & -0.216 & $(-)$ & Holmwood & -0.025 & $(-)$ \\
\hline Ambewela & -0.327 & $(-)$ & Dunedin Estate & -0.045 & $(-)$ \\
\hline Ratnapura & -0.009 & $(-)$ & Colombo & 0.1437 & $(+)$ \\
\hline Labukele Estate & -0.293 & $(-)$ & Katunayake & 0.0962 & $(+)$ \\
\hline Bopatthalawa NLDB & -0.204 & $(-)$ & $\begin{array}{l}\text { Hakgala } \\
\text { Botanical } \\
\text { Gardens }\end{array}$ & 0.0344 & $(+)$ \\
\hline Nuwara Eliya & -0.069 & $(-)$ & Katugastota & 0.0893 & $(+)$ \\
\hline Undugoda Estate & -0.057 & $(-)$ & Ratmalana & 0.2745 & $(+)$ \\
\hline
\end{tabular}

Table 6 - The Trend Analysis of Temperature Stations in and around Kelani Ganga Basin on Tmax Averages for Annual, Maha Season and Yala Season based on ITA, M-K and Sen's Slope Estimates

\begin{tabular}{|c|c|c|c|c|c|c|c|c|c|}
\hline \multirow[b]{2}{*}{$\begin{array}{l}\text { Name of the } \\
\text { Temperature } \\
\text { Station }\end{array}$} & \multicolumn{3}{|c|}{ For annual averages } & \multicolumn{3}{|c|}{$\begin{array}{c}\text { For averages for Maha } \\
\text { season }\end{array}$} & \multicolumn{3}{|c|}{$\begin{array}{c}\text { For averages for Yala } \\
\text { season }\end{array}$} \\
\hline & $\begin{array}{l}D \text { in } \\
\text { ITA }\end{array}$ & $\begin{array}{c}\text { Zin } \\
\text { in } \mathbf{M}- \\
\mathbf{K} \\
\text { test }^{1}\end{array}$ & $\begin{array}{l}Q_{m e d} \text { in } \\
\text { SSE }\end{array}$ & $\begin{array}{l}D \text { in } \\
\text { ITA }\end{array}$ & $\begin{array}{c}Z \text { in in } \\
M-K \\
\text { test }^{1}\end{array}$ & $\begin{array}{l}Q_{m e d} \text { in } \\
\text { SSE }\end{array}$ & $\begin{array}{l}D \text { in } \\
\text { ITA }\end{array}$ & $\begin{array}{l}Z \text { in } \\
M-K \\
\text { test }^{1}\end{array}$ & $\begin{array}{l}Q_{m e d} \text { in } \\
\text { SSE }\end{array}$ \\
\hline Badulla & -0.11 & -0.78 & -0.01 & -0.14 & -1.48 & -0.02 & -0.04 & -0.78 & -0.02 \\
\hline
\end{tabular}




\begin{tabular}{|c|c|c|c|c|c|c|c|c|c|}
\hline \multirow[b]{2}{*}{$\begin{array}{l}\text { Name of the } \\
\text { Temperature } \\
\text { Station }\end{array}$} & \multicolumn{3}{|c|}{ For annual averages } & \multicolumn{3}{|c|}{$\begin{array}{c}\text { For averages for Maha } \\
\text { season }\end{array}$} & \multicolumn{3}{|c|}{$\begin{array}{c}\text { For averages for Yala } \\
\text { season }\end{array}$} \\
\hline & $\begin{array}{l}D \text { in } \\
\text { ITA }\end{array}$ & $\begin{array}{c}\text { Zin } \\
\text { in } M- \\
K \\
\text { test }^{1}\end{array}$ & $\begin{array}{l}Q_{\text {med }} \text { in } \\
\text { SSE }\end{array}$ & $\begin{array}{l}D \text { in } \\
\text { ITA }\end{array}$ & $\begin{array}{c}Z \text { in in } \\
M-K \\
\text { test }^{1}\end{array}$ & $\begin{array}{c}Q_{\text {med }} \text { in } \\
\text { SSE }\end{array}$ & $\begin{array}{l}D \text { in } \\
\text { ITA }\end{array}$ & $\begin{array}{l}Z \text { in } \\
M-K \\
\text { test }^{1}\end{array}$ & $\begin{array}{c}Q_{\text {med }} \text { in } \\
\text { SSE }\end{array}$ \\
\hline Bandarawela & 0.07 & 1.24 & 0.01 & 0.01 & -0.26 & 0.00 & 0.12 & 1.24 & 0.01 \\
\hline Colombo & -0.03 & 0.07 & 0.00 & -0.05 & -0.07 & 0.00 & 0.00 & 0.07 & 0.00 \\
\hline Katugastota & 0.01 & 1.02 & 0.01 & -0.03 & -0.31 & 0.00 & 0.07 & 1.02 & 0.01 \\
\hline Katunayaka & -0.10 & -1.87 & -0.01 & -0.15 & -2.49 & -0.02 & -0.05 & -1.87 & -0.01 \\
\hline Kurunegala & 0.00 & 0.61 & 0.00 & -0.05 & -0.31 & 0.00 & 0.03 & 0.61 & 0.01 \\
\hline Nuwara Eliya & -0.06 & 0.72 & 0.00 & -0.09 & -0.53 & 0.00 & 0.01 & 0.72 & 0.01 \\
\hline Ratmalana & 0.00 & 1.19 & 0.01 & -0.02 & 0.59 & 0.00 & 0.05 & 1.19 & 0.01 \\
\hline Ratnapura & -0.02 & 0.31 & 0.00 & -0.04 & 0.04 & 0.00 & 0.00 & 0.31 & 0.00 \\
\hline Seetha Eliya & 0.00 & 0.72 & 0.01 & 0.01 & 0.31 & 0.00 & 0.03 & 0.72 & 0.01 \\
\hline
\end{tabular}

Table 7 - The Trend Analysis of Temperature Stations in and around Kelani Ganga Basin on $T_{\min }$ Averages for Annual, Maha Season and Yala Seasons based on ITA, M-K and Sen's Slope Estimates

\begin{tabular}{|c|c|c|c|c|c|c|c|c|c|}
\hline \multirow[b]{2}{*}{$\begin{array}{l}\text { Name of the } \\
\text { Temperature } \\
\text { Station }\end{array}$} & \multicolumn{3}{|c|}{ For annual averages } & \multicolumn{3}{|c|}{ For Maha averages } & \multicolumn{3}{|c|}{ For Yala averages } \\
\hline & $\begin{array}{l}\text { Din } \\
\text { ITA }\end{array}$ & $\begin{array}{l}Z \text { in } \\
M-K \\
\text { test }^{1}\end{array}$ & $\begin{array}{c}Q_{m e d} \text { in } \\
\text { SSE }\end{array}$ & $\begin{array}{c}D \\
\text { inITA }\end{array}$ & $\begin{array}{l}Z \text { in } \\
M-K \\
\text { test }^{1}\end{array}$ & $\begin{array}{c}Q_{m e d} \text { in } \\
\text { SSE }\end{array}$ & $\begin{array}{l}\text { Din } \\
\text { ITA }\end{array}$ & $\begin{array}{l}\text { Zin } \\
\text { M-K } \\
\text { test }^{1}\end{array}$ & $\begin{array}{c}Q_{m e d} \text { in } \\
\text { SSE }\end{array}$ \\
\hline Badulla & -0.01 & 0.07 & 0.00 & -0.14 & 0.00 & 0.00 & -0.01 & -0.45 & 0.00 \\
\hline Bandarawela & 0.49 & 1.24 & 0.01 & 0.01 & -0.26 & 0.00 & 0.49 & 0.91 & 0.01 \\
\hline Colombo & 0.18 & 0.07 & 0.00 & -0.05 & -0.07 & 0.00 & 0.18 & 0.23 & 0.00 \\
\hline Katugastota & 0.13 & 1.02 & 0.01 & -0.03 & -0.31 & 0.00 & 0.13 & 1.24 & 0.01 \\
\hline Katunayaka & 0.18 & 5.54 & 0.03 & -0.15 & 4.45 & 0.03 & 0.18 & 4.75 & 0.02 \\
\hline Kurunegala & 0.15 & 0.61 & 0.00 & -0.05 & -0.31 & 0.00 & 0.15 & 1.02 & 0.01 \\
\hline $\begin{array}{l}\text { Nuwara } \\
\text { Eliya }\end{array}$ & 0.27 & 0.72 & 0.00 & -0.09 & -0.53 & 0.00 & 0.27 & 0.78 & 0.01 \\
\hline Ratmalana & 0.18 & 5.71 & 0.03 & -0.02 & 5.03 & 0.03 & 0.18 & 4.97 & 0.03 \\
\hline Ratnapura & -0.06 & 0.31 & 0.00 & -0.04 & 0.04 & 0.00 & -0.06 & 0.48 & 0.00 \\
\hline Seetha Eliya & 0.49 & 0.72 & 0.01 & 0.01 & 0.31 & 0.00 & 0.49 & 0.61 & 0.01 \\
\hline
\end{tabular}

4.1.3 Climate Trend Analysis based on Streamflow data

All selected three streamflow gauging stations exhibit significant downward trends for the period of 1980 to 2016, as per the results of M-K test. Glencourse hydrometric station exhibits a significant decreasing trend in $\mathrm{M}-\mathrm{K}$ test for Maha averages at 5\% confidence level, while it shows a significant decreasing trend for annual averages and for Yala season at 1\% confidence level. Kitulgala station exhibits a significant decreasing trend in $\mathrm{M}-\mathrm{K}$ test for annual averages at a $10 \%$ confidence level, while it shows a significant decreasing trend for Yala season at a 5\% confidence level (Table 8 ) from 1980 to 2016. The Sen's slope trend magnitude varies between -2.2 to -0.3 for annual, Maha and Yala averages for the period of 1980-2016. The Hanwella exhibits the highest downward trend for annual, Maha and Yala seasons among three selected stations, while it shows significant downward trends for annual, four rainfall seasons, Maha and Yala seasons for only M-K test. 
Table 8 - The Trend Analysis of Flow at Hydrometric Stations in and Around Kelani Ganga Basin

\begin{tabular}{|l|r|r|r|r|r|r|r|r|r|}
\hline \multirow{2}{*}{$\begin{array}{c}\text { Station } \\
\text { Name }\end{array}$} & \multicolumn{3}{|c|}{ For annual averages } & \multicolumn{3}{c|}{ For Maha averages } & \multicolumn{3}{c|}{ For Yala averages } \\
\cline { 2 - 10 } & $\begin{array}{c}\text { Din } \\
\text { ITA }\end{array}$ & $\begin{array}{c}\text { Zin M- } \\
\text { K test }^{1}\end{array}$ & $\begin{array}{c}Q_{\text {med }} \text { in } \\
\text { SSE }\end{array}$ & $\begin{array}{c}D \text { in } \\
\text { ITA }\end{array}$ & $\begin{array}{c}Z \text { in } \\
\text { M-K } \\
\text { test }\end{array}$ & $\begin{array}{c}\mathbf{Q}_{\text {med }} \text { in } \\
\text { SSE }\end{array}$ & $\begin{array}{c}\text { Din } \\
\text { ITA }\end{array}$ & $\begin{array}{c}Z \text { in M- } \\
\text { K test }^{1}\end{array}$ & $\begin{array}{c}Q_{\text {med }} \text { in } \\
\text { SSE }\end{array}$ \\
\hline Kitulgala & -2.43 & -1.65 & -0.27 & -2.09 & -0.97 & -0.13 & -2.67 & -2.17 & -0.31 \\
\hline Glencourse & -3.60 & -3.04 & -1.77 & -3.18 & -2.19 & -1.12 & -4.06 & -2.93 & -1.83 \\
\hline Hanwella & -3.04 & -3.39 & -2.01 & -2.74 & -2.66 & -1.67 & -2.75 & -3.28 & -2.15 \\
\hline
\end{tabular}

\subsection{SWAT Modelling}

Among 41 selected rainfall gauging stations, only 32 most neighbouring rainfall gauging stations and 10 temperature gauging stations were used for SWAT modelling for the duration of 1960 to 2016. Therefore, the SWAT model is used to predict the streamflows for future scenarios for 2040 including land use for 2040.

Hargreaves method [29] was used to calculate evapotranspiration in SWAT. It is evident that there is a good agreement between the two methods between January and May in Colombo. After May, the actual evaporation data is higher than the calculated values, while the situation is reversed after mid-October. There is generally a good agreement between the two methods at Seetha Eliya with values generally higher than the measured evaporation data, especially after the month of August.

\subsubsection{Selection of Model Parameters and Objective Function}

Glencourse gauging station is selected as the key hydrometric station in the basin, as it is located in the narrow gorge section and it is the best gauging station in terms of data quality compared with the others in the Kelani Ganga basin. The durations for calibration and validation were selected based on the best quality observed data available periods for the Kelani Ganga basin.

By visualizing the daily simulated flow vs. observed flow, it is identified that peak flow and baseflow are the most sensitive parameters for optimization, hence rules for parameter regionalization were used to select the parameters [30]. During the sensitivity analysis, about seven (7) parameters were initially chosen for optimization [30] and finalized with four (4) parameters. Optimized four parameters are Threshold depth of water in the shallow aquifer required for return flow to occur (CN2.mgt), Threshold depth of water in the shallow aquifer required for return flow to occur (GWQMN.gw), Available water capacity of the soil layer (SOL_AWC().sol) and Soil evaporation compensation factor (ESCO.bsn) for the selected, which indicated the highest model sensitivity for the three selected objective functions. The Nash-Sutcliffe Efficiency (NSE), Relative Error $(E r)$ and Coefficient of determination $\left(R^{2}\right)$ were used to assess the SWAT model performance as suggested in the literature [23, 31]. Repeated sensitivity model runs were performed to optimize the three objective functions for Glencourse hydrometric station by changing four parameters using SUFI-2 parallel processing using SWAT-CUP. Due to the discrepancies in the data resolution, the actual resolution of the data series is not recorded, as the daily time step is used in the observed data series. Hence, the one-day time lag is adjusted in the observed time series to match the modelled flow series, to optimise objective functions.

Generally, model performance is termed very good if NSE $>=0.75$, satisfactory if 0.36 $=<N S E<0.75$, and unsatisfactory if NSE $<0.36$ $[31,32,33]$, while $R^{2}$ should be greater than 0.5 [33] and Er values are lower than 20\% [32]. The objective functions of NSE, $R^{2}$ and Er obtained are $0.65,0.72$ and $8.9 \%$ for calibration and 0.69 , 0.69 and $9.1 \%$, for validation, respectively. Hence, the overall performance of the model in terms of $R^{2}$, NSE and $E r$ is quite satisfactory for Glencourse hydrometric station. Though the obtained $R^{2}$ and $E r$ for Hanwella gauging station are satisfactory for calibration period with $0.6,7.3 \%$, the obtained NSE is very low such as 0.23 for the calibration period. None of the objective functions performed satisfactorily for Kitulgala station, presumably due to data inconsistencies. 


\subsubsection{Model Performance and Reliability 4.2.2.1 Flow Threshold Selection}

The threshold for low flows and high flows were taken as $80 \%$ and $15 \%$, respectively, for Glencourse gauging station, by visual observation of the deflection change of the Flow Duration Curve (FDC).

\subsubsection{Model Performance}

Model performance was checked by mainly NSE and $R^{2}$ for daily time-step. Low flow and high flow regions were identified for Glencourse. Though the satisfactory model performance is achieved for the objective functions for overall and high flow regions, the medium and low flow regions were unable to achieve the satisfactory model performance for NSE for calibration and validation periods. The NSE was very low as -0.63 and 0.00 for validation and calibration periods, respectively, for the medium flow region. Though the low flow region shows satisfactory model performance for objective functions for the validation period, it was unable to achieve satisfactory performance for the calibration period for $\mathrm{R}^{2}$, but the NSE was good for both calibration and validation of the model for the low flow region.

\subsection{Runoff Elasticity \\ 4.3.1 Current Scenario}

Climate change is always linked to a lot of uncertainties, hence Climate change predictions are also very sensitive especially for a small island like Sri Lanka when downscaling of GCM results to small grid sizes.

It clearly shows that a $1^{\circ} \mathrm{C}$ of temperature increase will cause a $6.9 \%$ to $7.5 \%$ runoff decrease, while a $1 \%$ of rainfall increase will cause $0.002 \%$ and $0.400 \%$ runoff increase at Glencourse gauging station as [25] and [23], respectively, hence temperature increase causes a higher impact on runoff than rainfall does for the current scenario for both methods (Table 9).

Table 9 - The Climate Elasticity for Glencourse Gauging Station for the Period 1980 to 2016 Based on the Methods Considered

\begin{tabular}{|l|c|c|}
\hline \multicolumn{1}{|c|}{$\begin{array}{c}\text { Climate Elasticity }(\varepsilon) \\
\text { defined as }\end{array}$} & $\varepsilon_{p}$ & $\varepsilon_{T}$ \\
\hline Zheng et al. (2009) [24] & 0.002 & -6.860 \\
\hline $\begin{array}{l}\text { Sankarasubramanian et al. } \\
\text { (2001) [22] }\end{array}$ & 0.372 & -7.450 \\
\hline
\end{tabular}

\subsubsection{Future Scenario}

Climate elasticity was estimated for Glencourse hydrometric station for the Baseline (Existing) and Future Pessimistic Scenarios for 99 years based on the simulated streamflow by SWAT model with projected landuse for 2040. As landuse change caused only a $0.1 \%$ flow increase at Glencourse, it is evaluated that the landuse change does not act as a significant impact on streamflow increase for 2040.

A $1^{\circ} \mathrm{C}$ increase in temperature causes a $0.4 \%$ rise and $1.5 \%$ reduction of runoff as evaluated by [24] and [22], respectively, for the Future Pessimistic Climate change Scenario with projected landuse for 2040. A 1\% of rainfall increase causes a $0.005 \%$ and $0.360 \%$ increase of streamflow as evaluated by [24] and [22], respectively, for Glencourse gauging station for the aforementioned scenario. This implies a positive effect on runoff for the future pessimistic scenario with projected landuse for 2040 as of [24].

\section{Conclusions and Recommendations}

\subsection{Conclusions}

1. Among 41 rainfall stations, 20 stations exhibit positive trends, while 17 stations show negative trends for annual rainfall totals for all three tests of ITA, MannKendall and Sen's slope. The Sen's slope trend magnitude varies between -30.2 to 30.0 for annual rainfall totals for the period of 1980-2016.

2. More than two-thirds of the rain gauge stations in the middle and upper basins in the Kelani Ganga basin show significant decreasing trends for high to low rainfall totals for Yala season as ITA analysis for the period of 1980 to 2016.

3. Among the selected 10 temperature stations, five (5) stations exhibit positive trends and two (2) stations show negative trends for annual averages, while one (1) station exhibits positive trend and 2 stations show negative trends for averages for Maha season and 8 stations exhibit positive trends, and 2 stations show negative trends for averages for Yala season for all three tests for the period of 1980-2016 for $T_{\max }$ series.

4. Among 10 temperature stations, eight (8) stations exhibit positive trends for annual averages, while one (1) station only exhibits a positive trend for averages for Maha season and eight (8) stations exhibit positive trends for Yala season for all three tests for the period of 1980-2016 for $T_{\min }$ series. 
5. All selected three hydrometric gauging stations exhibit significant downward trends for the period of 1980 to 2016. Hanwella exhibits the highest downward trend for annual, Maha and Yala seasons among three selected stations for all three tests, while it only shows a significant downward trend for annual, four rainfall seasons, Maha and Yala seasons for M-K test at a different level of significance.

6. It clearly shows that Climate elasticity is reduced after allowing for landuse influences on Climate change for both scenarios. A $1^{\circ} \mathrm{C}$ increase of temperature causes $6.9 \%$ and $7.4 \%$ runoff decrease and $1 \%$ increase of rainfall causes $0.002 \%$ and $0.370 \%$ runoff increase at Glencourse gauging station for the current scenario for both methods for the duration of 1980 to 2016.

7. Mass balance performance error (Er), coefficient of determination $\left(R^{2}\right)$ and NashSutcliffe efficiency (NSE) were used as multi-objective functions and $8.90 \%, 0.72$, 0.65 and $9.10 \%, 0.69,0.69$ are obtained, respectively, for the calibration and validation periods for the key hydrometric station at Glencourse.

8. A $1^{\circ} \mathrm{C}$ temperature increase in the basin causes a $0.4 \%$ rise and $1.5 \%$ reduction of runoff as evaluated by the methods proposed by Zheng et al. [24] and Sankarasubramanian et al. [22], respectively, for the Future Pessimistic Climate change Scenario with projected landuse for 2040. A $1 \%$ of rainfall increase causes a $0.005 \%$ and $0.360 \%$ increase of flow as evaluated by Zheng et al. [24] and Sankarasubramanian et al. [22], respectively, for Glencourse gauging station for the aforementioned scenario. This implies a positive effect on runoff for future pessimistic scenario with projected landuse for 2040 following the method proposed by Zheng et al. [24].

\subsection{Recommendations}

As the SWAT model has been calibrated and validated for the duration of 1970 to 1992, the results show a high degree of uncertainty of flow simulation for recent years. Hence, it is recommended to perform a water allocation model to obtain better calibration and validation results for the Kelani Ganga basin in future with consideration of identified trends after 1995, as water allocation models present the water users' contribution in the basin.Thus, the runoff will be reduced than that of the hydrological models at each node. Hence,the use of water allocation models could result in better calibration and validation results, which will reduce the degree of uncertainties on flow simulations for recent years after the 1990s as well as increase the degree of confidence to predict runoff elasticity coefficients for future scenarios in future researches for planning and management of water resources.

\section{Acknowledgements}

The manuscript is based on the findings of the postgraduate research carried out by the main author. The gratitude is extended to Eng. D. C. S. Elakanda, Project Director, Climate Resilience Improvement Project and Eng. (Mrs). P. A. A. P. K. Pannala, Deputy Project Director (CRIP), for providing their support to complete the Master's degree. Thanks are also provided to all the organizations, including the Irrigation Department, Department of Meteorology, and Mahaweli Authority, Sri Lanka for providing data to carry out this study.

\section{References}

1. Uniyal, B., Jha, M. K., and Verma, A. K., "Assessing Climate change Impact on Water Balance Components of a River Basin Using SWAT Model," Water Resour. Manag., Vol. 29, No. 13, pp. 4767-4785, Oct. 2015, doi: $10.1007 /$ s11269-015-1089-5.

2. "Summary for Policymakers of IPCC Special Report on Global Warming of $1.5^{\circ} \mathrm{C}$ approved by governments - IPCC." https:/ / www.ipcc.ch/2018/10/08/summaryfor-policymakers-of-ipcc-special-report-onglobal-warming-of-1-5c-approved-bygovernments/ (accessed Jan. 20, 2020).

3. Gosain, A. K., Rao, S., and Basuray, D., "Climate change Impact Assessment on Hydrology of Indian River Basins," Curr. Sci., Vol. 90, No. 3, pp. 346-353, 2006.

4. Kamran, M., and Rajapakse, L., "Effect of Watershed Sub division and Antecedent Moisture Condition on HEC-HMS Model Performance in the Maha Oya Basin, Sri Lanka," Aug. 2018. doi: 10.15282/ijets.5.2.2018.1004.

5. Mwakalila, S., Campling, P., Feyen, J., Wyseure, G., and Beven, K., “Application of a Data-Based Mechanistic Modelling (DBM) Approach for Predicting Runoff Generation in Semi-arid Regions," Hydrol. Process., Vol. 15, No. 12, pp. 2281-2295, Oct. 2001, doi: 10.1002/hyp.257. 
6. Jha, M., Arnold, J. G., Gassman, P. W., Giorgi, F., and Gu, R. R., "Climate change Sensitivity Assessment on Upper Mississippi River Basin Streamflows Using Swat1," JAWRA J. Am. Water Resour. Assoc., Vol. 42, No. 4, pp. 997-1015, 2006, doi: $\quad$ https://doi.org/10.1111/j.17521688.2006.tb04510.x.

7. Arumugam, S., Water Resources of Ceylon its Utilization and Development. Water Resources Board publications, Colombo, Sri Lanka, p. 415, 1969.

8. "WMO Guidelines on the calculations of Climate Normals E-Library." https:/ / library.wmo.int/index.php?lvl=notice_ display\&id=20166\#.XiTtTsgzY2w (accessed Jan. 20, 2020).

9. MWS\&D, "Western Province Metropolitan Area Water Supply Master Plan Update", Volume V, Water Resources Modelling Study, 2013.

10. Gleick, P. H., "Climate change, Hydrology, and Water Resources," Rev. Geophys., Vol. 27, No. 3, pp. 329-344, 1989, doi: https:// doi.org/10.1029/RG027i003p00329.

11. Jyrkama, M. I., and Sykes, J. F., “The Impact of Climate change on Spatially Varying Groundwater Recharge in the Grand River Watershed (Ontario)," J. Hydrol., Vol. 338, No. 3, pp. 237-250, May 2007, doi: 10.1016/j.jhydrol.2007.02.036.

12. Yang, H., and Yang, D., "Derivation of Climate Elasticity of Runoff to Assess the Effects of Climate change on Annual Runoff: Derivation of Climate Elasticity of Runoff," Water Resour. Res., Vol. 47, No. 7, Jul. 2011, doi: 10.1029/2010WR009287.

13. Wijesinghe, T. W. A. W., "Status of Water Quality of Kelani River", Central Environmental Authority, IIIRR online publication No. 255, (2010) Sri Lanka.

14. Şen, Z., "Innovative Trend Analysis Methodology," J. Hydrol. Eng., Vol. 17, No. 9, pp. 1042-1046, Sep. 2012, doi: 10.1061/(ASCE)HE.1943-5584.0000556.

15. WS Atkins International Ltd, "Flood and Drought Risk Assessment Report", Volume 01, Consultancy Services for Development of Basin Investment Plans (DBIP) for selected Basins, 2019.

16. Sen, P. K., "Estimates of the Regression Coefficient Based on Kendall's Tau," J. Am. Stat.
Assoc., Vol. 63, No. 324, pp. 1379-1389, Dec. 1968, doi: 10.1080/01621459.1968.10480934.

17. $\mathrm{Wu}, \mathrm{H}$. , and Qian, H., "Innovative Trend Analysis of Annual and Seasonal Rainfall and Extreme Values in Shaanxi, China, since the 1950s: Trend in Annual and Seasonal Rainfall and Extreme Values in Shaanxi," Int. J. Climatol., Vol. 37, No. 5, pp. 2582-2592, Apr. 2017, doi: $10.1002 /$ joc. 4866 .

18. Şen, Z., "Innovative Trend Analysis Methodology," J. Hydrol. Eng., Vol. 17, No. 9, pp. 1042-1046, Sep. 2012, doi: 10.1061/(ASCE)HE.1943-5584.0000556.

19. Tang, Y., Tang, Q., Tian, F., Zhang, Z., and Liu, G., "Responses of Natural Runoff to Recent Climatic Variations in the Yellow River Basin, China," Hydrol. Earth Syst. Sci., Vol. 17, No. 11, pp. 4471-4480, Nov. 2013, doi: 10.5194/hess-174471-2013.

20. Chiew, F. H. S., "Estimation of Rainfall Elasticity of Streamflow in Australia," Hydrol. Sci. J., Vol. 51, No. 4, pp. 613-625, Aug. 2006, doi: 10.1623/hysj.51.4.613.

21. Fu, G., Charles, S. P., and Chiew, F. H. S., "A Two-Parameter Climate Elasticity of Streamflow Index to Assess Climate change Effects on Annual Streamflow: Climate change Effects on Streamflow," Water Resour. Res., Vol. 43, No. 11, Nov. 2007, doi: 10.1029/2007WR005890.

22. Sankarasubramanian, A., Vogel, R. M., and Limbrunner, J. F., "Climate Elasticity of Streamflow in the United States," Water Resour. Res., Vol. 37, No. 6, pp. 1771-1781, Jun. 2001, doi: 10.1029/2000WR900330.

23. Niemann, J. D., and Eltahir, E. A. B., "Sensitivity of Regional Hydrology to Climate changes, with Application to the Illinois River Basin," Water Resources Research, 41(7), 2005. https:/ / doi.org/10.1029/2004WR003893.

24. Zhang, X., Srinivasan, R., Debele, B., Hao, F., "Runoff Simulation of the Headwaters of the Yellow River using the SWAT Model with Three Snowmelt Algorithms", J Am Water Res Assoc 44(1):48-61, 2008.

25. Srinivasan, R., Ramanarayanan, T. S., Arnold, J. G., Bednarz, S. T., " Large Area Hydrologic Modeling and Assessment: Part II. Model Application", J Am Water Resour Assoc 34(1):91102, 1998. 
26. Neitsch, S. L., Arnold, J. G., Kiniry, J. R., and Williams, J. R., "Soil and Water Assessment Tool Theoretical Documentation Version 2009", Texas Water Resources Institute, 2011.

27. Hamed, K. H., and Ramachandra Rao, A., “A Modified Mann-Kendall Trend Test for Autocorrelated Data", Journal of Hydrology, 204(1-4), 182-196, 1998, https://doi.org/10.1016/S0022-1694(97)00125-X

28. Wickramagamage, P., "Spatial and Temporal Variation of Rainfall Trends of Sri Lanka," Theor. Appl. Climatol., Vol. 125, No. 3-4, pp. 427-438, Aug. 2016, doi: 10.1007/s00704-015-1492-0.

29. Kra, E., “FAO-56 Penman-Monteith Daily E T o from Linear Regression Calibrated Hargreaves Equation with Wind Terms in Tropics with Limited Data," Int. J. Agron., Vol. 2014, pp. 1-9, 2014, doi: 10.1155/2014/402809.

30. Abbaspour, K. C., Rouholahnejad, E., Vaghefi, S., Srinivasan, R., Yang, H., and Kløve, B., “A
Continental-Scale Hydrology and Water Quality Model for Europe: Calibration and Uncertainty of a High-Resolution Large-scale SWAT Model," J. Hydrol., Vol. 524, pp. 733-752, May 2015, doi: 10.1016/j.jhydrol.2015.03.027.

31. Nash, J. E., and Sutcliffe, J. V., "River Flow Forecasting through Conceptual Models: Part I. A Discussion of Principles", J. Hydrol., 10, 282290,1970 .

32. Kra, E., "FAO-56 Penman-Monteith Daily E T o from Linear Regression Calibrated Hargreaves Equation with Wind Terms in Tropics with Limited Data," Int. J. Agron., Vol. 2014, pp. 1-9, 2014, doi: 10.1155/2014/402809.

33. Moriasi, D. N., Arnold, J. G., Van Liew, M. W., Bingner, R. L., Harmel, R. D., and Veith, T.L., "Model Evaluation Guidelines for Systematic Quantification of Accuracy in Watershed Simulations", Transactions of the ASABE, 50(3), 885-900,2007. 